\title{
The Relationship between Teachers Teaching Experience Attitude, Classroom Interaction Pattern and Students Academic Achievement in Science Subjects in Ebonyi State
}

\author{
Chinyere G Attamah \\ Biology Department \\ Ebonyi state College of Education \\ Ukpai Patricia Ogonnaya \\ Biology Department \\ Ebonyi State College of Education Ikwo
}

\author{
Chisom Precious Attamah \\ Department of Biology \\ Alex Ekweme Federal University Ndufu Alike \\ Chidi Nwobashi \\ Chemistry Department \\ Ebonyi state college of Education
}

Abstract:- This study investigated the relationship between teachers teaching experience, attitude, classroom interaction pattern and student's academic achievement of science students in public secondary secondary school in Ebonyi State. This research adopted the expost facto research design. The population for this study consisted of teachers teaching science in senior secondary classes. A sample of $\mathbf{1 0 0}$ sechools were chosen for the study using stratified random sampling technique, the basis of stratification being the 3 senatorial zones of the state. 33 public schools were selected from Ebonyi south and Ebonyi north and 34 from Ebonyi central. Three instruments were used to collect data, The FIAC, the science teachers variable questionnaire (STVQ) and science subject achievement test (SSAT). The hypothesis was posited for the study and was analyzed using 0.05 alpha level of significant. Hypothesis one was tested using one way analysis of variance and Pearson product moment correlation was used to test hypothesis two and three respectively. The result of hypothesis one show a significant f-ratio for $1 / \mathrm{D}(\mathrm{F}=4.556 \mathrm{p}<0.05)$ and insignificant f-ratio of $1.529 \mathrm{D} / \mathrm{st}$ ratio. Given the sig $\mathrm{f}$ ration of 1/D ratio, the result of $L C D$ that teachers with 6 - 10 yrs has high. 1/D ratio than all other teachers while those with 21 yrs of experience was insignificant. The result of hypothesis two shows that $0.00 \mathrm{r}$ value for 1/D ratio and $r=0.18 \mathrm{D} / \mathrm{st}$ ratio. This indicates no significant relation between teachers attitude and their classroom interaction pattern. On hypothesis three the result indicates positive relationship between achievement in science and classroom interaction with $1 / \mathrm{D}(\mathrm{r}=0.19)$ and $\mathrm{D} / \mathrm{st}$ ratio $(r=0.39)$ the critical value $r_{c}=0.19$. Findings revealed that teaching experience has a lot to do with classroom interaction pattern which is positively related to students academic achievement and not science teachers attitude has no relationship with their classroom interaction pattern. This paper concluded that most teachers use direct teaching method whereas some science subjects curriculum content requires both direct and indirect teaching method. Nevertheless, science teachers should use more of indirect teaching methods because science is an activity based subject.

\section{INTRODUCTION}

Science can be said to be any system of knowledge that is concerned with the physical world and its phenomena, that entails unbiased observation and systematic experimentation. It also involves a pursuit of knowledge covering general truths or the operation of fundamental law (online dictionary 2012)

Teaching has been identified to have two major objectives in secondary school: first is the teaching for personal use and secondly teaching for community purpose (Attamah \& Aloh 2016). The 2007 science curriculum identified the personal use of teaching science as helping an individual develop physical skills, social skills and also train an individual in science courses in higher institution while the community use of science involves preparing an individual in such a way that he/she can pass the knowledge of science to next generation.

Bajah (1984) in Attamah \& Aloh (2016) has a similar view of the NCDC when he opined that science teaching is very important to secondary school students, the community and the nation at large because it is basically the study of life and its surrounding environment. Science subject is one of the subjects in secondary school curriculum that has helped in meeting the need of pupil especially their curiosity and inquisitiveness about nature.

Science related subjects are problem solving subjects because it stimulates in man awareness of its immediate environment, inculcates logical thinking and enhances skill acquisition. The study also helps students to be honest, respectful and diligent.

Despite the fact that science subjects are well known subjects, there are still negative observations related to it, which include poor performance of science amongst secondary school students, wrong perception among 
secondary students, poor attitude towards science subjects. Baja (1984) is of the view that poor performance of secondary school students in science related subjects is not as a result of any difficulty in science content but rather a result of science teacher's mode of communicating science.

A science teacher especially in secondary school level should be a constructive teacher possessing high level of skills. This will enable him to create a kind of classroom environment whereby learning can occur in learners through organizing their thought questioning, analyzing, interpreting and drawing conclusion. In this case the mistake they make and the problems they meet becomes essential part of learning process (Ezewe 1987)

Teaching behavior exists in a context of social interaction, the act of teaching leads to reciprocal contact between the teacher and the learner, and its interchange itself is called teaching Adam (1967) in Attamah \& Aloh (2016)

Classroom interaction refers to chains of event which occur one after the other each occupying only a small segment of time Flanders (1977) in Attamah \& Aloh (2016). When the same sequence of event occurs again and again such a sequence can be called pattern. Teachers are in contact with pupil constantly during their secondary education and the extent these contacts are influential largely depend on the effectiveness of the teacher in question. Secondary school science teachers should note that it is in the classroom that pattern of thinking should be set; students' attitude towards the course should be shaped. They should also be conscious of the fact that active participation of students can influence their growth of independence and self direction (Penik 1999).

It is essential to note that science teachers are instructional leaders of their classes, teachers being this has some variables and traits that govern their mode of operation in class (Ezewe 1986). Such variable include; personality, gender, age, attitude, qualification and teaching experience etc.

Teaching experience can be said to be those methodology, texts and skills of teaching learned overtime through constant practice. Thorndike (1913) law of effect stressed the role of practice; Hull (1943) in Onuoha (1999) throws more light in the definition when he emphasized the role repetition plays in habit formation and also in habit strengthening.

Attitude can be said to be manner, disposition, feeling position of a person towards another thing Dictionary.com (2012). The Encyclopedia Americans 2010 defines attitude as a predisposition to respond in a certain way to a person, object, situation, events or ideas. Attitude can also be the regularization of an individual's feelings, thoughts and predisposition to act towards certain stimulus. Baja in Attamah \& Aloh (2016) found out the problems associated with academic achievement of students learning science, he revealed that one of the problems that causes poor academic performance of pupil in science subject was not from the content area of the curriculum rather it was associated with the attitude formed by the teachers and students towards science subjects.

This paper therefore seeks to investigate the relationship between teachers teaching experience. Teacher's attitude, classroom interaction and student's academic achievement of science students.

To be able to conduct this research, the following research hypotheses were formulated:

$>$ Classroom interaction pattern of science teachers do not differ significantly with respect to their teaching experience.

$>$ Teacher's attitude towards science is not significantly related to their classroom interaction pattern.

$>$ Student's academic achievements in science are not significantly related to the classroom interaction pattern.

\section{LITERATURE REVIEW}

There is a psychologist principle that says practice makes perfect, Onuoha 1999 tend to support this principle when he asserts that there is need to practice when learning such basic skills as reading, writing and arithmetic. The work of Davis (2014) shows teachers with more teaching experience reported higher level of efficiency towards teaching and is rated more highly by their students. The study of Oluwakenin and Olukajodi (2015) opined that schools having more teachers with 10 years of teaching experience achieved better result than school having teachers with less than 10 years teaching experience in English language. On the impact of teaching experience on teaching effectiveness in colleges Shamon, thrice and more (1998) divided teaching experiences into three categories: (1) No previous teaching experience (2) No college teaching experience (3) College teaching experience. They concluded that teachers with college teaching experience were rated as more effective than those without such experience. Grossman (1991) in his view confirms the popular philosophical saying that experience is the best teacher when he said that experimental knowledge is very essential for teaching effectiveness and this is obtained through years of repeated contacts and experimentation with students. Onuoha (1999) in his view states that teacher's years of experience has only indirect effect on students' academic achievement. This indirect effect which has a coefficient of 0.19 accounts for 6.26 on the total effect of the ten independent variables and also accounts for 3.96 of the variable of students' academic achievements. The indirect effect tends to incorporate teacher's classroom interaction.

Attitude can be said to be a predisposition to respond in a certain way to a person, object, situation, events or ideas (American dictionary 2010). Attitude can also be manner, disposition, feeling, position of a person towards another thing. It is the regularization of individual's feeling, thoughts and predisposition to act towards certain 
stimulus. This means that the way a teacher behaves, conducts himself and gives his lesson has a long way to determine the extent his/her students understand the lesson which in turn affects his academic achievements. The work of Paul, Ude and Nyejirime (2019) in Teachers' attitude as a correlate of student's academic performance opined that attitude of teachers correlated positively and significantly with student's academic performance. Mucella, Melas and Ahn (2011) found that teachers' positive attitudes have positively influenced students' personality as well as their life performance. Ormered and Thekwom (1995) opined that teacher's attitude plays a great role in their teaching and learning of science. These works indicate that science teacher who shows positive attitude towards science tends to communicate science very well and the learning achievement of their students tend to be high.

Classroom interaction analysis refers to technique of objective and systematic observation of the classroom for the study of teacher's classroom behavior and the process of interaction going on inside the classroom Flanders (1997) in Attamah \& Aloh (2016). Classroom interaction analysis maybe defined as an instrument which is designed to record categories of verbal interaction during or from recorded teaching and learning session. Ruhela 1995 in Attamah \& and Aloh (2016) opined that classroom Interaction might be divided into two parts verbal and non verbal interaction. They defined verbal interaction as spoken words the teacher and the students speak in class as class room instruction is going on. This verbal interaction includes teachers question, teachers lecturing, students question and answers and teachers instructions. $\mathrm{He}$ identified non verbal interaction as those signs students and teachers display to show they encode, decode or did not decode. It involves nodding of head, shaking of head, facial expressions etc.

Different authors has analyzed classroom interaction in this paper Flanders interaction analyses (FIAC) was used.FIAC is useful in classroom analysis because it can be used for analysis of classroom behavior, representation of classroom behavior, measuring instrument for classroom teaching, evaluating device, feedback device useful for theories of teaching.

FIAC consists of 10 categories of communication, which are said to be inclusive of all communication possibilities. There are seven categories used when the teacher is talking and two when the pupil is talking and tenth for silence or confusion in which communication cannot be understood by the observer.

\section{RESEARCH METHODOLOGY}

The Research design for this study is ex-post factor research design. The essence of this study was to determine the extent to which teacher's variables influences classroom interaction and academic achievement of science students. In the type of study the variable of the teacher are already there, and cannot be manipulated.

\section{$>$ Population of Study}

The population for the study consisted of teacher's teaching science (Biology \& Chemistry and Physics) in senior secondary classes of SS3 public schools in Ebonyi State and student in SS3 classes offering science courses.

\section{$>$ Sample Procedure}

The stratified random sampling was adopted for the study the stratification was based on the three sensational zones in the state. From the population of SS3 in the public secondary school, 100 schools were chosen for the study.

Three instruments were used to obtain data for the study:

- The Flanders Interaction Analysis Categories (FIAC) was used to get data on classroom interaction dependent variable.

- The Science Teacher Variable Questionnaire (STVQ) was used to obtain data on independent variable.

- The Science Subject Achievement Test (SSAT) was used to obtain data on students' achievement in science subjects.

\section{$>$ Data Collection Procedure}

The researchers and aid trained by them entered the classes and observed the class session and also recorded each session. The coding was done every 10 seconds. The observers indicated with a strike the behavior that occurred.

The STVQ was admitted personally to the 100 science teachers immediately after an observed lesson and was retrieved on the spot.

A 50 question (SSAT) was administered in the class with the assistance of the science teachers to answer after class.

\section{$>$ Data Preparation}

The data gathered from the classroom observation was tabulated into composit matrix. The indirect student ratio (1/D ratio) and direct ratio (D/st Ratio) were computed for each teacher using the formular

$1 / \mathrm{D}$ ration $=\frac{\text { sum of categories } 1234}{\text { sum of categories } 567}$

$\mathrm{D} / \mathrm{st}$ ratio $=\underline{\text { sum of categories } 567}$ sum of categories 89

The scoring for STVQ was as follows

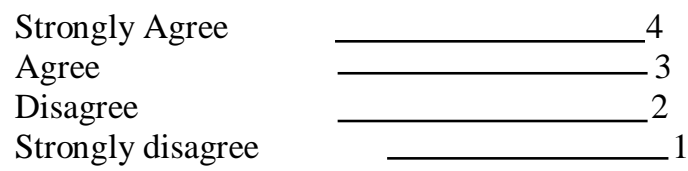

On attitude, there were 14 items on the slide the items were rated positively. Any teacher who scored below 31 did not show positive attitude towards teaching of science. 
For teaching experience was coded as below:

$1-5$ years 1

$6-10$ years 2

$11-20$ years 3

21 and above 4.

\section{HYPOTHESIS TESTING AND RESULT INTERPRETATION}

\section{$>$ Hypothesis I}

The null hypothesis speculated that classroom interaction pattern of science teachers do not differs significantly with respect to their teaching experience. The hypothesis was tested using one was analysis of variance and the result showed in table 1.

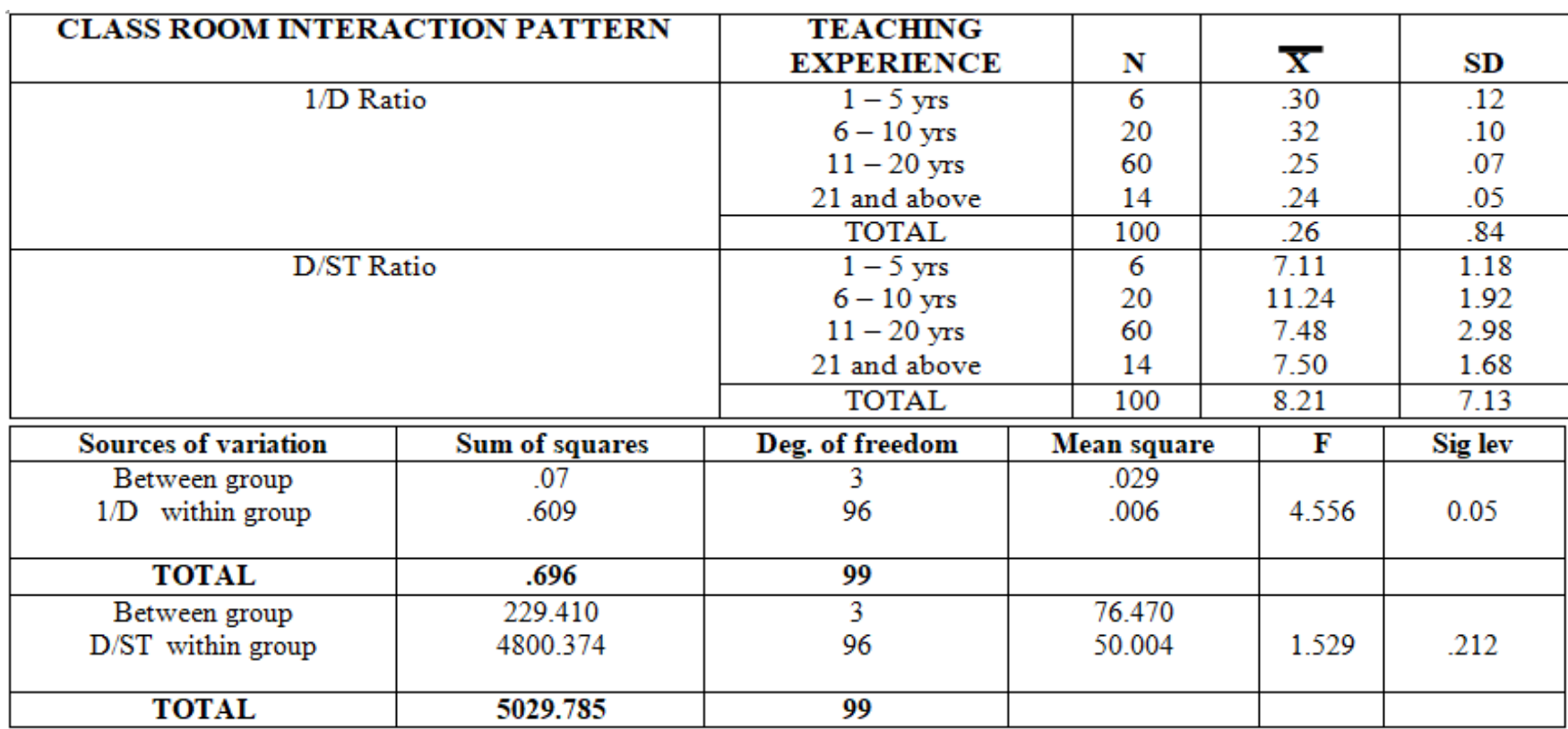

Table 1

Examination of the result in table I show that teachers with $6-10$ yrs of teaching experience had the highest mean of $1 / \mathrm{D}$ ratio $\overline{\mathrm{X}} .32$. This indicates that these teachers used more of indirect teaching than others. This value was followed by teachers with $(1-5) \bar{X}=30.11-20$ yrs form mean $\bar{X}=0.25$, and $21 \mathrm{yrs}$ and above. However since the $1 / \mathrm{D}$ ratio is all less than one, it means that all the teachers used more of direct teaching strategies. With respect to D/ST ratio Table I showed that teachers with $6-11 \mathrm{yrs}$ had highest mean of $\mathrm{D} / \mathrm{ST}$ ratio $(\mathrm{X}=11.24)$. Then 21 and above $(\mathrm{X}=7.50), 11-20 \mathrm{yrs}(\mathrm{X} 7.48)$, then $1-5 \mathrm{yrs}$ with $(\mathrm{X}=$ 7.11). When these means were compared using the one way ANOVA results showed a sig $\mathrm{f}$ ratio for $1 / \mathrm{D}$ ratio $(\mathrm{f}=4.556$, $\mathrm{P}<.05)$ and insignificant $\mathrm{f}$ ratio for $\mathrm{D} / \mathrm{ST}$ ratio $(\mathrm{f}=1.529$;
$\mathrm{P}>$.05). The result of $\mathrm{D} / \mathrm{ST}$ ratio the null was retained while for $1 / \mathrm{D}$ ration, the null was rejected.

Given the significant f-ratio for $1 / \mathrm{D}$ ratio a multiple comparison test using LCD was done to locate the source of difference. The result of the analysis presented in table 2 . The result in table 2 shows that teachers with $6-10$ years have significant higher $1 / \mathrm{D}$ ratio value than teachers with 11 -20 years of experience $(\mathrm{t}=3.29 \mathrm{P}<0.05)$ and those with 21 years and above $(\mathrm{t}=2.76 ; \mathrm{P}<0.05)$. Other pairwise comparison was not significant.

The result implies that teacher with $6-10$ years of teaching experience use more indirect teaching strategy than teachers with 11 years and above teaching experience.

\begin{tabular}{|c|c|c|c|c|}
\hline Teaching Experience & $\begin{array}{c}1-5 \\
(\mathrm{n}=6)\end{array}$ & $\begin{array}{c}6-10 \text { years } \\
(\mathrm{n}=20)\end{array}$ & $\begin{array}{c}11-20 \text { yrs } \\
(\mathrm{n}=60)\end{array}$ & $\begin{array}{c}21 \text { and above } \\
(\mathrm{n}=14)\end{array}$ \\
\hline $1-5$ & $.30^{\mathrm{a}}$ & $0.138^{\mathrm{b}}$ & .0539 & 0.638 \\
\hline $6-10$ & $-0.3^{\mathrm{c}}$ & .32 & .0677 & 0.795 \\
\hline $11-20$ & 1.58 & 3.29 & .25 & 0.099 \\
\hline 21 and above & 1.64 & 2.76 & 0.42 & 0.24 \\
\hline
\end{tabular}

$\mathrm{P}<0.5$

Table 2:- Fishers least sig difference LCD multiple comparison test of influence of teaching experience on biology interaction pattern $1 / \mathrm{D}$ ratio. 
$>$ Hypothesis 2

The null hypothesis speculated that teachers attitude towards science are not significantly related to their classroom interaction pattern. Pearson product moment correlation was used to analyze the hypothesis. The result presented in table 3.

\begin{tabular}{|c|c|c|c|}
\hline Variable & $\bar{X}$ & SD & $\mathrm{R}$ \\
\hline Attitude $(\mathrm{X})$ & 31.28 & 7.37 & 0.00 \\
\hline 1/D ratio & .26 & 1.08 & -0.18 \\
\hline D/ST ratio & 8.22 & 7.13 & \\
\hline
\end{tabular}

$\mathrm{P}>.05, \mathrm{df}=98$, critical $\mathrm{r}=0.19$

Table 3:- Pearson product moment correlation analysis of the relationship between teachers' attitude and their classroom interaction pattern. $(\mathrm{n}=100)$

Examination of the result in table 3 shows that there is no significant relationship between teachers attitude and their classroom interaction pattern $1 / \mathrm{D}$ ratio $(\mathrm{r}=0.00 ; \mathrm{P}>0.5, \mathrm{D} / \mathrm{ST}$ ratio $\mathrm{r}=-0.18 ; \mathrm{P}>.05)$

The null hypothesis was therefore retained for pattern of interaction (I/D and D/St ratio)

\section{$>$ Hypothesis 3}

The null hypothesis stated that students academic achievement in science does not significantly relate to their teacher's classroom interaction pattern. To test this hypothesis, Pearson product moment correlation Analysis was done. The result showed on table 4

\begin{tabular}{|c|c|c|c|}
\hline Variables & Mean $(\mathrm{X})$ & SD & $\mathrm{R}$ \\
\hline Academic & 40.82 & 6.50 & \\
\hline Achievement $(\mathrm{X})$ & & & .19 \\
\hline 1/D ratio $\mathrm{y}_{1}$ & .26 & .08 & .39 \\
\hline D/ST ratio $\mathrm{y}_{2}$ & 8.22 & 7.13 & \\
\hline
\end{tabular}

$\mathrm{P}>$.05. $\mathrm{df}=98$, critical $\mathrm{r} 0.19$

Table 4:- Pearson product moment correlation of the relationship between students achievement in science student and classroom interaction pattern $(\mathrm{n}=100)$

Observation from table 4 shows that there is a significant positive relationship between achievement in science and classroom Interaction pattern with $1 / \mathrm{D}$ ratio $(\mathrm{r}=$ $0.19 \mathrm{P}<0.5)$ and $\mathrm{D} / \mathrm{St}$ ratio $(\mathrm{r}=.39 ; \mathrm{P}<0.5)$. The null hypothesis was rejected because the calculated $r$ value $(0.19)$ and (0.39) is equal and higher than the critical value of $r=0.19$.

The positive r-value obtained means that the higher the students' achievement the better the classroom interaction pattern tends to be, whether direct or indirect. Conversely the lower the students' achievement, the less favorable the classroom interaction pattern tends to be.

The result can be summarized as follows

- Teaching experience was found to have a significant influence on the classroom interaction pattern (1/D ratio) in science classroom. On the land $\mathrm{D} / \mathrm{st}$ ratio was found not to be significantly influenced by teaching experience in science classroom. This is indicated that teachers with 11 years and above teaching experience and many other teachers use more of direct teaching method.

- Teachers attitude were found not to significantly relate to their classroom interaction pattern (D/st and 1/D).

- The result indicated that there was a significant relationship between science students' academic achievement and science teacher's classroom interaction.

\section{DISCUSSION}

This work revealed that teaching experience was found to significantly influence the classroom interacting pattern (1/D ratio).Attamah \& Aloh 2016 stated that teachers with long experience on their job are bound to be knowledgeable in their area of specialization. Onoha (1999) revealed that teachers year of experience only has indirect effect on students academic performances on the contrary Akpan (2007) found no significant relation on teaching experience and classroom interaction pattern.

On the attitude of teachers towards science subjects, this work revealed that teachers' attitude towards science subject is not significantly related with their classroom interaction .The work of Paul, Ude and Ahu (2019) found teachers positive attitude to positively influence students' personality. This work collaborates the work of Akpan (2007) who found that attitude of social studies teachers has not influenced on their classroom interaction pattern.

The result on student academic achievement in science and classroom interaction pattern shows a positive relation between the 1/D and D/st ratio and achievement in science. In collaboration to this finding Attamah \& Aloh found a positive relationship between students academic achievement in biology and classroom interaction pattern. Powell (1998) found that indirect teaching was associated with higher score but for reading, direct teaching showed 
more positive relationship. La sher and Westmeysin (2001) related directedness of teacher's behavior to pupil achievement gain.

Summarily, this work revealed the relevancy of direct and indirect teaching method in science classes. There are some curriculum content, which need direct or indirect teaching strategies, nevertheless science subject being an activity oriented subject requires more of indirect teaching methods and strategies

\section{RECOMMENDATION}

Government should from time to time give appropriate, intensive and well supervised inservice training to teachers with more than 10years of teaching experience differently from the normal teachers training to avoid the law of diminishing return.

$>$ Teachers' trainee should expose appropriate method/strategies to the science teachers through workshop and seminars so that they will know the best way to stimulate learning in pupil.

$>$ Science teachers should update themselves through personal studies and in service training.

$>$ Science student should on their own read ahead of their teachers, this will enable them to actively participate in teaching and learning process and also identify area of difficulties in that topic.

\section{REFERENCES}

[1]. Akpan, F.A (2007). Relationship among teacher's variable classroom interaction pattern and students learning achievement in social studies. Unpublished PHD dissertation, University of Calabar. Nigeria.

[2]. Attamah, C.G and Aloh, O.G (2016). The relationship between teacher's personality, classroom interaction and student Academic Achievement in Biology in Enugu. South East COEASU Journal of Teachers Education (SECJOTE). .Pgs 185 - 192. Volume 3 No (I) Sept 2016

[3]. Baja, C (1984). Teaching science in secondary school. Ibadan. New publisher.

[4]. Dictionary.com (2012) online Edition William Collins sons and Co. Ltd.

[5]. Ezewe, O (1987). Social psychology factors of human learning in school. Onitcha: lead way

[6]. Grossman, P (1991). Mapping the terrain knowledge in teaching. In H.C Waxman and H.J Wallberg (Eds) Effective teaching current research, Berkely: MacCatcher, $78-92$.

[7]. Mucella Uking, Melas Sery Ozdeu, Ahu Eryilamoz (2011). The effect of teacher's attitudes on students' personality and performance procedings social and behavioral science. https://www.researchgate.net.

[8]. Oluwakemi Tomitope and Olukayode (2015). Teachers teaching experience and academic performance. International Journal Humanities, social science and Education Vol 2. https://www.researchgate.net.
[9]. Onuoha, S (1999). Correlation of teachers' variable and interaction pattern. Unpublished doctorial dissertation. University of Calabar, Nigeria.

[10]. Paul Ekperi, Ude Onwuka, Nyegirime Wike young (2019). Teachers attitude as acorrelate of students academic performance. https://www.researchgate.net.

[11]. Penuk, J. E (1991). Effective teaching of science. Journal of Research in science teaching 19(5) $233-240$. 